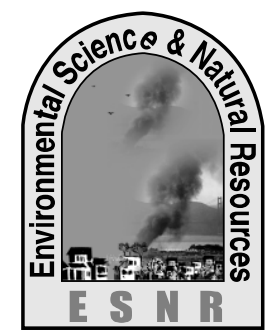

\title{
Variation in Morphological Characters and Yield Attributes of Five Selected Soybean Genotypes
}

\author{
D. Sultana ${ }^{1}$, M. N. Bari ${ }^{1}$, M. A. Karim ${ }^{1}$, M. A. B. Mia ${ }^{2}$ and R. R. Sarker ${ }^{3 *}$ \\ ${ }^{1}$ Department of Agronomy, ${ }^{2}$ Department of Crop Botany, \\ Bangabandhu Sheikh Mujibur Rahman Agricultural University, Salna, Gazipur \\ ${ }^{3}$ Soil Science Division, Bangladesh Institute of Nuclear Agriculture, Mymensingh-2202 \\ "Corresponding author: rrssarker@gmail.com
}

\begin{abstract}
A field experiment was conducted at the experimental field of the Bangabandhu Sheikh Mujibur Rahman Agricultural University, Gazipur during November 2013 to March 2014. Four soybean genotypes i.e BU Soybean1, BD2329, BD2331, AGS313 and a check variety BARI Soybean 6 were used to evaluate their variations in morphological characters and yield attributes. The experiment was laid out in a Randomized Complete Block Design (RCBD) with three replications. The highest LAI (4.4) was found in genotype AGS313 and the smallest was found in BU Soyabean1. The highest pod size of $625 \mathrm{mg} \mathrm{pod}^{-1}$ was found in AGS313 while the lowest of $340 \mathrm{mg}$ pod $^{-1}$ was observed in BU Soybean1. Although BU Soyabean1 had smaller seed size but it had higher number of pods plant ${ }^{-1}(32.1)$ compared to other genotypes. The maximum 100-seed weight was recorded in AGS313 (16.34 g) and the minimum was obtained from the genotype BU Soybean1 $(11.0 \mathrm{~g})$. AGS313 genotype contributed to the highest grain yield of 4.29 tha $^{-1}$, while BU Soyabean1 stood second position contributing 2.65 tha $^{-1}$. Results also indicated that not only seed size but also number of pods plant ${ }^{-1}$ contributed to grain yield. Again there were highly significant differences among genotypes for all the characters
\end{abstract}

Key words: Morphology, Soyabean genotypes, Yield performance

\section{Introduction}

Soybean [Glycine max (L.) Merril] is a grain legume crop and a popular source of vegetable protein and phytochemicals in many Asian countries (Rao et al., 2002). The demand of soybean is increasing day by day for human food as well as feed for animal and fish. As an oil seed crop, soybean ranks first in terms of area and production in the world. In Bangladesh, about 35,000 hectares of land is under soybean cultivation and annual production is approximately 70,000 metric tons with an average yield of 1.5-2.3 tha ${ }^{-1}$ (Awal, 2014). Recently the crop has gained popularity in the poultry industry and its cultivation area is gradually increasing that covers about 51,778 ha in Noakhali and Laxmipur districts only (Chowdhury, 2012). There was an effort to establish soybean in Bangladesh during 1980s. However, the attempt was not successful mainly due to lack of good variety, marketing channel and availability of quality seed. The problem with lack of good variety and seed quality, however, remains unresolved. Seed quality is essential to obtain a successful field emergence of soybean crop (Arango et al., 2006). The seed quality is mostly influenced by the temperature and moisture fluctuations (Harrington, 1972) which regularly occur in Bangladesh during the soybean harvest. There is a bright prospect for soybean production in Bangladesh and it is possible to meet 40 percent of local demand of soybean oil by bringing 0.7 0.8 million hectares of lands in char areas under cultivation with an expected production 1.7-1.8 million metric tons of soybean (Mollah, 2009). Due to rich and varied chemical composition it is widely used as a food, forage and industrial crop, having a great agro technological importance as well (Pimentel and Patzek, 2008; Sakai and Kogiso, 2008). Soybean seed is also used as fish and poultry feed. It can become an alternative source of protein and fat or the people of the country who cannot afford the animal protein like meat, fish, egg and milk. The consumption of soy-based products is increasing worldwide due to its enormous health related beneficial effects, which include reduction of cholesterol level, prevention of cancer, diabetes and obesity, protection against intestinal and kidney diseases (Friedman and Brandon, 2001). Seed yield of soybean is controlled by quantitative genes with low heritability that makes the response to selection for yield (Burton, 1987). This study was conducted to relate grain growth dynamics with yield performance of selected soybean genotypes.

\section{Materials and Methods}

The experiment was carried out at the experimental field of Bangabandhu Sheikh Mujibur Rahman Agricultural University (BSMRAU), Gazipur during November 2013 through March 2014. Four selected soybean genotypes with high yield potential and a check variety were included in the investigation. The genotypes were BARI Soybean 6 (variety), BU Soyabean1, BD2329, BD2331, AGS313. The experiment was laid out in a Randomized Complete Block Design (RCBD) with three replications. All fertilizers were applied before final land preparation. Irrigation was given whenever necessary. At physiological maturity, dry pods were harvested at different days after sowing (DAS) for different genotypes. The harvesting was started from 105 DAS and continued up to 115 DAS for different genotypes. The crop was harvested on maturity. Data were recorded on different parameters, viz. plant height, Leaf area index (LAI), number of pods plant ${ }^{-1}$, number of branches plant ${ }^{-1}$, number of seeds pod- ${ }^{1}, 100$-seed weight, seed yield $\left(\mathrm{gm}^{-2}\right)$, straw yield and harvest index. The data in respect of all parameters were analyzed following analysis of variance (ANOVA) technique with the help of computer package, Statistics 10. The means for all the treatment were calculated and the analysis of variance for all the characters was performed by F- test. Significance of the difference 
among the means was evaluated by LSD (Least Significance Difference) at 5\% level of probability.

\section{Results and Discussion}

\section{Plant height}

Genotypes showed significant difference in plant height (Fig.1). The tallest plant was observed in AGS313 (58cm) while the shortest was in BU

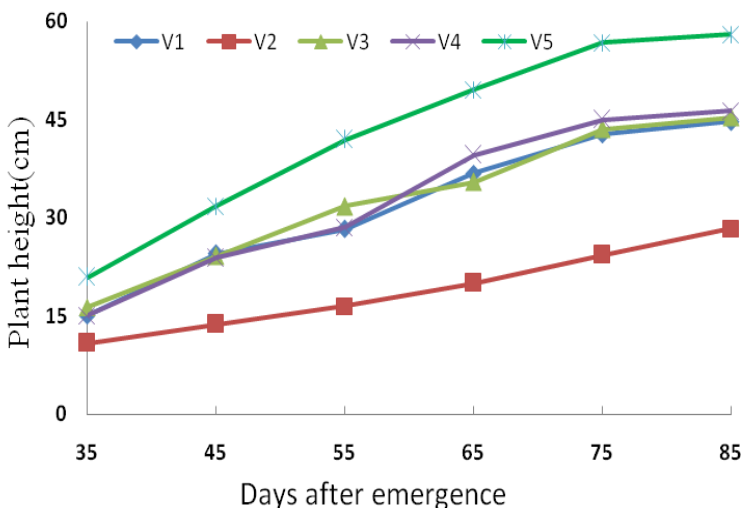

Fig. 1. Plant height of five soybean genotypes at different growth stages

\section{$\mathrm{V} 1=\mathrm{BARI}$ Soybean \\ Leaf area index (LAI)}

LAI measured at different growth stages of each genotype was statistically different from each other (Fig.2). At 85 DAE (Days after emergence), AGS313 (4.4) showed higher LAI, being followed by BD2329, whereas lower LAI was observed in BU Soyabean1 (1.56). After 85 DAE, LAI declined sharply which might be due to leaf senescence and dropping of older leaves. There was a positive correlation between LAI and yield (Table 3 ).
Soyabean1 $(29 \mathrm{~cm})$. Similar plant height $(31 \mathrm{~cm})$ and $(30 \mathrm{~cm})$ for BU Soyabean1 was observed by Awal (2014) and Pankaj (2013), respectively. The variation observed in plant height among the genotypes might be due to the difference in genetic constituents as well as environmental effects.

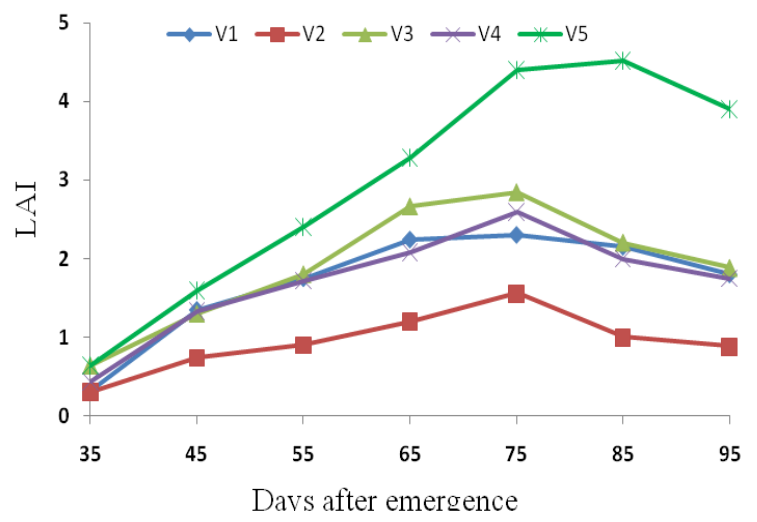

Fig. 2. Leaf area index of five soybean genotypes at different growth stages

Table 1. Yield contributing characters of five soybean genotypes

\begin{tabular}{llccc}
\hline \multicolumn{1}{c}{ Genotype } & $\begin{array}{l}\text { Number of branches } \\
\text { plant }^{-1}\end{array}$ & Pods plant $^{-1}$ & Seeds Pod $^{-1}$ & 100 seed weight(g) \\
\hline BARI Soybean6 & $7.0 \mathrm{~b}$ & $19.1 \mathrm{~d}$ & $1.73 \mathrm{c}$ & $13.89 \mathrm{ab}$ \\
BU Soybean1 & $8.3 \mathrm{a}$ & $32.1 \mathrm{a}$ & $1.90 \mathrm{bc}$ & $11.03 \mathrm{~b}$ \\
BD2329 & $6.0 \mathrm{c}$ & $21.9 \mathrm{~cd}$ & $1.86 \mathrm{bc}$ & $13.38 \mathrm{ab}$ \\
BD2331 & $5.7 \mathrm{~d}$ & $25.0 \mathrm{bc}$ & $1.98 \mathrm{~b}$ & $13.77 \mathrm{ab}$ \\
AGS313 & $5.7 \mathrm{~d}$ & $28.9 \mathrm{ab}$ & $2.56 \mathrm{a}$ & $16.30 \mathrm{a}$ \\
\hline CV $(\%)$ & 9.5 & 10.28 & 5.64 & 8.44 \\
\hline
\end{tabular}

Different letters within a column indicate significant difference at $5 \%$ level of significance.

\section{Number of pods plant ${ }^{-1}$}

Number of pods plant ${ }^{-1}$ varied significantly (19.1-32.1) among the genotypes (Table 1). The highest number of pods plant ${ }^{-1}$ (32.1) was produced by BU Soybean1 which was followed by AGS313. The genotype BARI Soybean6 produced the lowest number of pods plant ${ }^{-1}$ (19.1) which was being followed by BD2329 \& BD2331. Wide variation in pods plant ${ }^{-1}$ (22 to 36$)$ was also reported by Singh and Hymowitz (1999). There was a positive relationship between pods plant ${ }^{-1}$ and grain yield (Table 3). Higher seed yield might be due to higher no. of pods plant ${ }^{-1}$ (Saha, 2005).

\section{No of branches plant ${ }^{-1}$}

The number of branches per plant varied among the soybean genotypes (Table 1). Significantly higher number (8.3) of branches was recorded in BU Soyabean1, while the lowest (5.7) was in AGS313 and BD2331. The result corroborated with that of Pankaj (2013) who observed that soybean genotypes varied in number of branches plant ${ }^{-1}$ due to variations in genotypic constituents. 
15.74 depending upon genotypic variation. A similar finding was recorded by Pankaj (2013) that 100-seed weight among genotype varies from 10.55 to 16.34 .

Table 2. Seed yield, straw yield and harvest index of 5 soybean genotypes

\begin{tabular}{lllll}
\hline Genotype & $\begin{array}{l}\text { Seed yield } \\
\left(\mathrm{gm}^{-2}\right)\end{array}$ & $\begin{array}{l}\text { Straw yield } \\
\left(\mathrm{gm}^{-2}\right)\end{array}$ & $\begin{array}{l}\text { Seed yield (tha } \\
1)\end{array}$ & Harvest Index (HI) \\
\hline BARI Soybean6 & $161.00 \mathrm{c}$ & $198.08 \mathrm{~b}$ & $1.54 \mathrm{~d}$ & $44.6 \mathrm{c}$ \\
BU Soybean1 & $194.33 \mathrm{~b}$ & $170.67 \mathrm{~d}$ & $2.65 \mathrm{~b}$ & $53.24 \mathrm{a}$ \\
BD2329 & $135.00 \mathrm{~d}$ & $223.50 \mathrm{a}$ & $1.8433 \mathrm{~cd}$ & $40.1 \mathrm{e}$ \\
BD2331 & $161.20 \mathrm{c}$ & $200.03 \mathrm{~b}$ & $2.04 \mathrm{c}$ & $41.6 \mathrm{~d}$ \\
AGS313 & $216.98 \mathrm{a}$ & $192.00 \mathrm{bc}$ & $4.29 \mathrm{a}$ & $52.79 \mathrm{~b}$ \\
\hline CV $(\%)$ & 0.78 & 0.63 & 0.3931 & 0.90 \\
\hline
\end{tabular}

Different letters within a column indicate significant difference at $5 \%$ level of significance.

Seed yield $\left(\mathrm{gm}^{-2}\right)$

Seed yield differed significantly among the genotypes (Table 2). AGS313 produced the highest seed yield $\left(216.98 \mathrm{gm}^{-2}\right)$, being followed by BU Soybean1 (194.33 $\left.\mathrm{gm}^{-2}\right)$. The lowest yield was found in BD2329 (135 gm ${ }^{2}$ ). AGS313 had larger seed size compared to others, which might have contributed to its higher grain yield than others. Although BU Soybean1 had the lower 100seed weight, it ranked second in seed yield, which might be due to its higher no. of pods plant ${ }^{-1}$. The finding was in accordance with Awal (2014) who stated that the seed yield of soybean varied among genotypes for their difference in genetic makeup.

\section{Straw yield}

Straw yield differed among the genotypes (Table 2). The highest straw yield $\left(223.50 \mathrm{gm}^{-2}\right)$ was obtained from BD2331 while the lowest was in BU Soybean1 (170.67 $\mathrm{gm}^{-2}$ ) followed by AGS313 (192.0 $\left.\mathrm{gm}^{-2}\right)$. However, when total dry matter production was the concern, genotype AGS313 had the maximum (408.98 $\mathrm{gm}^{-2}$ ) followed by BU Soybean1 $\left(365.0 \mathrm{gm}^{-2}\right)$, which indicated that AGS313 and BU Soybean1 accumulated more dry matter in pod rather than increasing biomass.

\section{Harvest index}

Varieties differed significantly in terms of harvest index (Table 2). The highest harvest index was found in genotype BU Soybean1 (53.24) and lowest was in BD2329 (40.1). There was a positive correlation between harvest index and yield. Correlation coefficient analysis of LAI, HI, Yield and pod plant ${ }^{-1}$ showed relationship (Table 3) among them. Negative sign indicates the relationship is negative.

Table 3. Correlation coefficient of LAI, HI, Yield and pod plant ${ }^{-1}$ in five soybean genotypes

\begin{tabular}{llcccc}
\hline & & LAI & HI & Yield & Pod plant $^{-1}$ \\
\hline LAI & Pearson Correlation & 1 & -0.043 & 0.335 & -0.027 \\
& Sig. (2-tailed) & & 0.945 & 0.582 & 0.966 \\
\multirow{3}{*}{ HI } & N & 5 & 5 & 5 & 5 \\
& Pearson Correlation & -0.043 & 1 & $0.883^{*}$ & 0.853 \\
& Sig. (2-tailed) & 0.945 & & 0.047 & 0.066 \\
\multirow{3}{*}{ Yield } & N & 5 & 5 & 5 & 5 \\
& Pearson Correlation & 0.335 & $0.883^{*}$ & 1 & 0.762 \\
& Sig. (2-tailed) & 0.582 & 0.047 & 5 & 5 \\
\multirow{2}{*}{ Pod } & N & 5 & 5 & 5 & 1 \\
& Pearson Correlation & -0.027 & 0.853 & 0.762 & 5 \\
& Sig. (2-tailed) & 0.966 & 0.066 & 5 & 5 \\
\end{tabular}

*. Correlation is significant at the 0.05 level (2-tailed).

\section{Conclusions}

Among five soybean genotypes AGS313 produced the maximum grain yield $\left(4.29\right.$ tha $\left.^{-1}\right)$ due to having the larger seed size. Therefore, increase in morphological traits will ultimately increase the grain yield. The morphological characters can be considered as selection criteria in improving the grain yield of soybean genotypes. 


\section{References}

Arango, M. R., A. R. Salinas, R. M. Craviotto, S. A. Ferrarf, V. Bisaro and M. S. Montero. 2006. Description of the environmental damage on soybean seeds [Glycine max (L) Merr]. J. Seed Sci. \& Technol. 34:133-141.

Awal, A. M. 2014. Grain yield and seed quality of early maturing dwarf soybean genotypes as influenced by planting time and spacing. Ph.D Dessetation. Dept. of Agronomy, BSMRAU, Gazipur. pp. 10-45.

Burton, J. W. 1987. Quantitative Genetics: Results Relevant to Soybean Breeding. In Soybeans: Improvement, Production and Uses, J.R. Wilcox, editor. American Society of Agronomy, Madison, Wisconsin, U. S. A., pp. 211-247.

Chowdhary, M. U. 2012. Prospect of soybean cultivation in Bangladesh (In Bangla). The Daily Jugantor, on 26 Sept.

Friedman, M. and D. L. Brandon. 2001. Nutritional and health benefits of soy proteins. J. Agric. Food Chem. 49: 1069-1086.

Harrington, J. F. 1972. Problems of seed storage. In Seed Ecology. (Ed. Heydecker). The Pennsylvania State University Press. pp.251-261.
Mollah, M. A. A. 2009. Bright prospect for soybean farming in Bangladesh. The Daily Star, on 27 Oct.

Pankaj, B. 2013. Plant Characterization and seed quality of some dwarf soybean genotypes. M.S. Thesis. Dept. of Agronomy, BSMRAU, Gazipur. pp. 24-53.

Pimentel, D. and T. Patzek. 2008. Ethanol production using corn, switchgrass and wood; biodiesel production using soybean. In: Biofuels, Solar and Wind as Renewable Energy Systems (Pimentel D. ed.), Springer, New York: 373-394.

Rao, M. S. S., B. G. Mullinix, M. Rangappa, E. Cebert, A. S. Bhagsari, V. T. Sapra, J. M. Joshi and R. B. Dadson. 2002. Genotype $\times$ environment interactions and yield stability of food-grade soybean genotypes. Agron. J. 94: 72-80.

Saha, R. R. 2005. Physiological aspects of yield and seed quality of Mungbean. Ph. D Dessertation, Dept. Of Agronomy, BSMRAU, Salna, Gazipur-1706.

Sakai, T. and M. Kogiso. 2008. Soy is of flavones immunity. J. Med. Invest. 55: 176-173.

Singh, R. J. and T. Hymowitz. 1999. Soybean genetic resources and crop improvement. Genome, 42: 605616. 